\title{
Genetic Characterization of Angiostrongylus Cantonensis Isolates from Different Regions of Ecuador
}

Caracterización Genética de Angiostrongylus Cantonensis Aislados de Diferentes Regiones de Ecuador

\footnotetext{
Luis Solórzano Alava ${ }^{1}$, Cesar Bedoya Pilozo ${ }^{2}$, Hilda Hernández Alvarez ${ }^{3}$, Misladys Rodriguez $^{4}$, Lazara Rojas Rivero ${ }^{5}$, Francisco Sánchez Amador $^{6}$, Marcelo Muñoz Naranjo ${ }^{7}$, Cecibel Ramirez ${ }^{8}$, Rita Loja Chango ${ }^{9}$, José Pizarro Velastegui ${ }^{10}$, Alessandra Loureiro Morasutti ${ }^{11}$

INFORMACIÓN DEL ARTÍCULO

Fecha de recepción: noviembre 5, 2020. Fecha de aceptación: febrero1, 2021.

${ }_{1}^{1}$ Especialista en laboratorio Clinico, Instituto Nacional de Investigación en Salud Pública "INSPI", Centro de Referencia Nacional de Docencia e Innovación, Guayaquil, Ecuador E-mail: 1solorzano@jbgye.org.ec Código ORCID:

https://orcid.org/0000-0002-9758-6663

2 Magister en Biotecnología molecular, Universidad de Guayaquil, Hospital "Luis Vernaza", Servicio de Laboratorio clinico Laboratorio de Biologia Molecular, Guayaquil, Ecuad
Código ORCID:

https://orcid.org/0000-0003-0448-8608

3 Ph.D en Ciencias, Instituto de Medicina Tropical Pedro Kour

https://orcid.org/0000-0003-0448-8608

4 Magister en Epidemiologia, Instituto de Medicina Tropical Pedro Kouri.

Código ORCID

https://orcid.org/0000-0001-9455-6103

5 Ph.D en Ciencias Médicas, Instituto de Medicina Tropical Pedro Kouri.

Código ORCID:

Codigo ORCID:
https://orcid.org/0000-0002-8070-5419

${ }^{6}$ Biólogo, Universidad de Guayaquil.

Código ORCID:

https://orcid.org/0000-0003-3566-6964

PhD en Fisiologia de invertebrados,

Universidad de Montpellier.

Código ORCID:

https://orcid.org/0000-0002-5379-5594

${ }^{8}$ Quimica Farmaceutica, Universidad de Guayaquil. Código ORCID:

https://orcid.org/0000-0002-1006-3879

9 Magister en Biotecnología molecular Universidad Católica de Santiago de Guayaquil. Código ORCID:

\begin{abstract}
Angiostrongylus cantonensis (Chen, 1945) was identified in Ecuador for the first time in 2008. Eleven provinces of the country were investigated to established the phylogenetic relationships between the isolates of the adult parasite and to compare them with those existing in other regions of the world. Partial region of subunit 1 of Cytochrome oxidase (COI 1) was amplified, amplicons were sequenced and aligned with the reference sequences of the AC1-AC9 haplotypes. Isolates are grouped in a single clade different from the other previously characterized groups, which represents a novelty for the genetic diversity of the parasite in Latin America and the rest of the world. The parasite has been recently introduced, which has prevented genetic divergence between the isolates.
\end{abstract}

\section{Keywords:}

Angiostrongylus cantonensis, phylogeny, COI 1, Ecuador.

JEL Classification: I10, I19.

\section{Resumen}

Angiostrongylus cantonensis (Chen, 1945) fue identificado en Ecuador por primera vez en 2008. Se investigaron once provincias del país para establecer las relaciones filogenéticas entre los aislados del parásito y compararlos con los existentes en otras regiones del mundo. Se amplificó la región parcial de la subunidad 1 del citocromo oxidasa (COI 1), se secuenciaron los amplicones y se alinearon con las secuencias de referencia de los haplotipos AC1-AC9. Los resultados demuestran que los aislamientos se agrupan en un solo clado diferente a los otros grupos previamente caracterizados, lo que representa una novedad para la diversidad genética del parásito en América Latina y el resto del mundo. Se concluye que el parásito ha sido introducido recientemente, lo que ha impedido divergencia entre los aislados.
}

https://orcid.org/0000-0001-6560-687X

${ }^{10}$ Magister en Enseñanza de Inglés como idioma extranjero, Escuela Superior politécnica del Litora. Código ORCID:

https://orcid.org/0000-0003-0558-8184

${ }^{11} \mathrm{PhD}$ en Zoología, Instituto de Patología e Biología Molecular de Passo Fundo, Passo Fundo, Brasil. Código ORCID

https://orcid.org/0000-0002-8142-1055

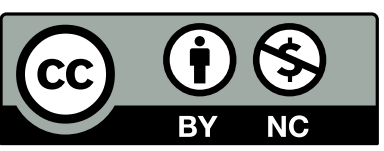

\section{Palabras Clave:}

Angiostrongylus cantonensis, filogenia, COI 1, Ecuador.

Clasificación JEL: I10, I19.

CITACIÓN: Solórzano, L., Bedoya, C., Hernández, H., Rodríguez, M., Rojas, L., Sánchez, F., Muñoz, M. Ramírez, C., Loja, R., Pizarro, J., Loureiro, A. (2021). Genetic Characterization of Angiostrongylus Cantonensis Isolates from Different Regions of Ecuador. Investigatio, 16, 52-61.

doi:10.31095/investigatio.2021.16.5

ENLACE DOI:

http://dx.doi.org/10.31095/investigatio.2021.16.5

INVESTIGATIO No. 16, Marzo 2021, pp. 52-61

(C) Universidad Espíritu Santo - UEES

ISSN: 1390-6399 ISSN-e: 2602-8336 


\section{Introduction}

Angiostrongylus cantonensis was first described in rats in Guangzhou (Canton), China, in 1935 (Chen, 1935). This nematode also infects humans and is the main cause of eosinophilic meningoencephalitis, an infectious disease of the central nervous system (CNS) and its membranes, characterized, among other aspects, by an increase in the proportion of eosinophils in cerebrospinal fluid and later in peripheral blood (Lindo et al., 2004). Since the first notification of human infection by $A$. cantonensis in Taiwan in 1945, more than 2,800 cases have been registered in different regions of the world (Wang et al., 2008).

In 2008, the first focus of natural transmission of $A$. cantonensis was described in Ecuador and the parasite was found in land snails, Achatina fulica ((Bowdich, 1922) as well as in rodents Rattus rattus (Linnaeus, 1758) and Rattus norvegicus (Berkenhout, 1769) (MartiniRobles L, Gomez E, Muzzio J, Solorzano L., 2016) and in human affected by the disease (Cedeño et al., 2008),(Pincay et al., 2009). Currently, the parasite is endemic in most of the country (Solorzano Alava et al., 2014). One of its main intermediate hosts is the so-called giant African snail Achatina fulica. This mollusk lives in urban and rural areas, and has an important role in the spread of the parasite, and is one of the main transmitters of eosinophilic meningoencephalitis and ocular angiostrongyliasis due to contaminated food, or by ingestion of raw snail (Moreira et al., 2013).
The genetic aspects of this parasite have been explored in a systematic and phylogenic way. The sequences of nuclear and mitochondrial genes have been used for molecular differentiation and phylogenetic analyzes of Angiostrongylus species (Galtier et al., 2009)

The mitochondrial COI gene represents a good marker for the study of the genetic evolution (phylogeny) of the different strains of $A$. cantonensis, and in the identification of haplotypes of the parasite (Monte et al., 2012).

The main objective of the study was establish the phylogenetic relationships of isolates of the parasite from different geographic locations in Ecuador, in relation to the isolates characterized in South America and the rest of the world. This study will allow us, firstly, to determine if there is genetic variation among the characterized Ecuadorian isolates and secondly, to establish phylogenetic relationships with variants described in different regions of the world. This information will allow us to establish guidelines on the genetic origin of the parasite in our country.

\section{Materials and Methods}

Between May 2017 and April 2019, 2.500 specimens of giant African snail ( $A$. fulica) were manually collected with the catch per unit effort method for 30 minutes (Muzzio, 2014). The collection was carried out in several locations in 11 provinces of Ecuador (Guayas, Manabí, 
Esmeraldas, El Oro, Santa Elena, Los Ríos, Sucumbíos, Napo, Pastaza, Orellana, Zamora Chinchipe). The snails were examined for L3 larvae of $A$. cantonensis using the modified Lobato-Paraense method for the extraction of the soft organs of the mollusks (Paraense \& Paraense, 1995). The paleal membrane was separated and placed in plates with $2.5 \mathrm{~mL}$ of digestion solution for 6 hours (Wallace \& Rosen, 1967) and they were observed to identify and counting the larvae (L3) according to previously described taxonomic characteristics (Thiengo et al., 2013), using a Motic SMZ-168 ${ }^{\mathrm{TM}}$ stereomicroscope.

The larvae (L3) obtained from snails collected in the eleven provinces selected for the study, were used to experimentally infect adult female rats Rattus novergicus, strain Wistar (12 weeks old and $200 \pm 2 \mathrm{~g}$ of body weight) from the INSPI Bioterium, with their corresponding health and genetic quality certificates in order to reproduce the biological cycle of the parasite, at the National Reference Center for Parasitology, females were chosen because we have observed that in these, the life cycle of the parasite is shorter compared to the male. The infected rats were separated into individual cages ( 2 specimens per cage) and identified according to the place of origin (province) of the intermediate hosts with which they were infected.

The handling of the animals was carried out according to the guide for the maintenance and use of experimental animals of the laboratory, following the Horizontal legislation on the protection of animals used for scientific purposes,
Directive 2010/63/EU as amended by Regulation (EU) 2019/1010 (Legislation for the protection of animals used for scientific purposes-Environment-European Commission, s. f.).

Once the average time of the parasite's life cycle had elapsed, the thoracic cavity of the rat (heart, pulmonary arteries and lungs) was examined in search of parasitic nematodes, juveniles or adults, according to protocols previously established in the INSPI (Solorzano Alava et al., 2014). Adult nematodes found in the pulmonary artery lumen were counted and stored in 90\% alcohol. The morphology of the bursa and the size of the caudal spicules were used as taxonomic characteristics for identification.

The parasites found in the two specimens from each province (between 15 and 30 parasites) were pooled together and were macerated and the DNA was extracted using the QIAamp ${ }^{\circledR}$ DNA Mini Kit (QIAGEN, Holland) reagent set, according to the manufacturer's protocol. The extracted DNA was identified according to its origin, it was stored at -80 ${ }^{\circ} \mathrm{C}$ until its amplification by PCR. DNA concentration was measured directly on a spectrophotometer (Nanodrop 2000, Thermoscientific, USA).

PCR was performed in $25-\mu$ l total volume containing $12.5 \mu \mathrm{l}$ of Promega GoTaq ${ }^{\circledR}$ DNA Polymerase $2 \mathrm{x}, 1.5 \mu \mathrm{l}$ of $10 \mu \mathrm{M}$ each primer, $5.5 \mu \mathrm{l}$ of distilled water and $4 \mu \mathrm{l}$ of DNA template. The PCR was carried out using a Bio-Rad brand thermocycler (C1000 Touch Thermal Cycler), with the primers 
previously reported for the selected genetic markers Primers used were CO1_F (5' TAAAGAAAGAACATAAT GAAAATG 3') and CO1_R (5' TTTTTT GGCATTCCTGAGGT') (Apichat et al., 2016).

Thermocycling was conducted as fol $\neg$ lows: $94^{\circ} \mathrm{C}$ for 5 minutes; followed by 30 cycles of $94^{\circ} \mathrm{C}$ for 1 minute, $48^{\circ} \mathrm{C}$ for 30 seconds, and $72^{\circ} \mathrm{C}$ for 1 minute; with a final heating at $72^{\circ} \mathrm{C}$ for 5 minutes. Am-plicons (450 bp) were analyzed by $1.2 \%$ agarose gel-electrophoresis.

1x TAE was used as a running buffer, $10 \mu 1$ of $\operatorname{Syber}{ }^{\circledR} 1 \mathrm{x}$ dye $(10000 \mathrm{x})$ (Invitrogen, Thermo Fisher Scientific, USA) was added to the agarose gel. As loading buffer, Blue/Orange Loading Dye, 6x (Promega, USA) was used, as a molecular weight marker TrackItTM $100 \mathrm{bp}(0.1 \mu \mathrm{g}$ $/ \mu \mathrm{L}$ ) (Invitrogen, Thermo Fisher Scientific, USA). The electrophoretic run was performed with the Bio-Rad brand power source (Bio-Rad PowerPac ${ }^{\mathrm{TM}} \mathrm{HC}$, USA) at $80 \mathrm{~V}$ for 55 minutes. The $450 \mathrm{bp}$ products were visualized on a photodocumenter (Bio-Rad ChemiDocTM XRS, Bio-Rad, USA).

The purification of the PCR products and the sequencing of the nucleotide chains corresponding to the provinces studied was carried out by the biochemistry service of the University of the Americas (Ecuador), with the use of the same primers used in the reaction of amplification. For the Sanger sequencing, an Applied Biosystems ${ }^{\circledR}$ 3130 Genetic Analyzer was used.

The resulting chromatograms were edited with the Geneious 7.0 program
(BIOMATTERS $\AA$ Australia). From the sense and anti-sense sequences of each amplified and sequenced sample, the consensus sequences or CONTIGS were constructed (Kearse et al., 2012). The assembled sequences were aligned with reference sequences representing clades $\mathrm{AC} 1$ to $\mathrm{AC13}$ using the MUSCLE algorithm of the MEGA 10 program (Kumar et al., 2018). The phylogenetic reconstruction was based on the maximum likelihood (ML) method using an evolutionary model Tn93 with a rate of invariable change and a bootstrap of 200 replicates, considering a cut-off point of 50\% (Arenas, 2015).

\section{Results}

In the various localities of the 11 Ecuadorian provinces where snails were collected, total percentage of snails infected with Angiostrongylus cantonensis was $12,16 \%(304 / 2500)$. The provinces with the highest prevalence percentages were: Napo with 24,19\% (52/215), El Oro with $23,46 \%$ (427178), Sucumbíos with $22,33 \% \quad(48 / 215) \quad$ Orellana $15,18 \quad \%$ (34/224), Zamora $10,70 \%(20 / 187)$ and Guayas $10,45 \%(30 / 287)$.

Tabla 1.

Distribution of snails (A.fulica) infected with $A$. cantonensis by provinces

\begin{tabular}{lccl}
\hline Provinces & Snails (n) & $\begin{array}{c}\text { Infected } \\
\text { snails (n) }\end{array}$ & $\begin{array}{c}\text { Prevalence } \\
(\mathbf{\%})\end{array}$ \\
\hline Guayas & 287 & 30 & 10,45 \\
Santa Elena & 271 & 22 & 8,12 \\
Los Rios & 266 & 21 & 7,89 \\
Sucumbíos & 215 & 48 & 22,33 \\
El Oro & 179 & 42 & 23,46 \\
Orellana & 224 & 34 & 15,18 \\
Pastaza & 198 & 9 & 4,55 \\
Esmeraldas & 210 & 11 & 5,24 \\
Zamora & 187 & 20 & 10,70 \\
Napo & 215 & 52 & 24,19 \\
Manabí & 248 & 15 & 6,05 \\
TOTAL & $\mathbf{2 5 0 0}$ & $\mathbf{3 0 4}$ & $\mathbf{1 2 , 1 6}$ \\
\hline
\end{tabular}


In figure 1 , it is possible to observe the phylogenetic tree where the Ecuadorian sequences are represented in relation to the sequences found in other parts of the world. All the Ecuadorian isolates are phylogenetically identical to each other and resemble the Ac5 and Ac8 haplotypes previously found in Brazil and Japan.

\section{Discussion}

Considering that there is no information on the genetics of this parasite in Ecuador. The present work proposes to establish the phylogenetic relationships of Ecuadorian specimens with isolates from other regions of the world.

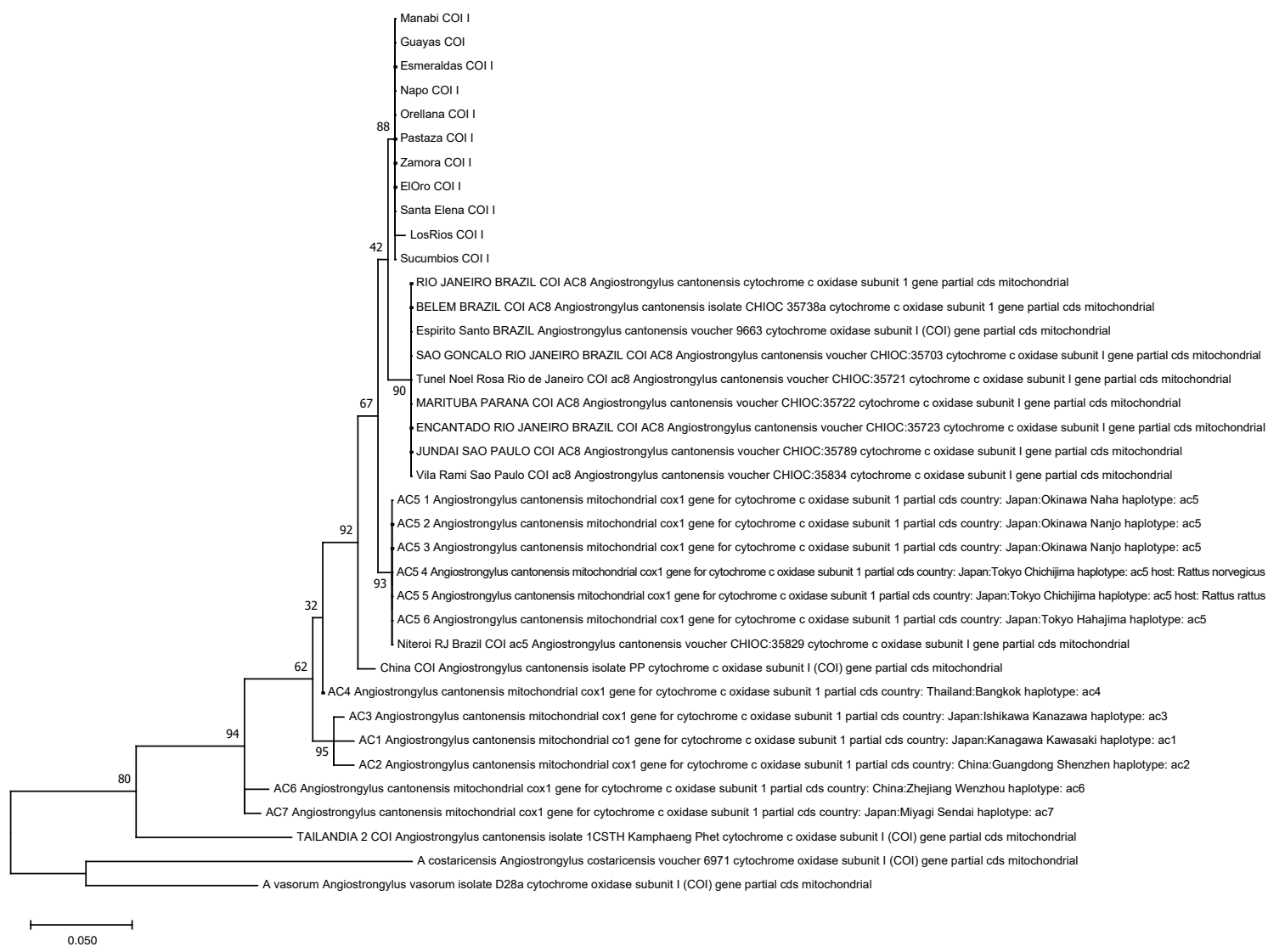

Figura 1. Phylogenetic tree of the Ecuadorian isolates of A. cantonensis taking as reference the sequences of the haplotypes AC1 AC9. The phylogenetic analysis was performed using the maximum likelihood method based on the evolutionary model Tn93 + I (Tamura - Nei + invariable rate of change) with 200 replications.
In a study conducted in Japan, sequences were determined for 83 adult parasites of $A$. cantonensis from 18 geographic locations in Japan, mainland China, Taiwan, and Thailand. Phylogenetic analysis showed 7 different haplotypes (AC1 to $\mathrm{AC7}$ ). The haplotypes found were 5 in Japan (AC1, AC2, AC3, AC5 and $A C 7), 2$ in mainland China (AC2 and AC6) and only one haplotype was identified from Taiwan (AC1). Similarly, only a single haplotype (AC4) was identified from two worms kept in a laboratory in Thailand. The lower genetic variation and the particular geographic distribution of $A$. cantonensis at each location could indicate a founder effect,

\section{6}

INVESTIGATIO No. 16, Marzo 2021, pp. 52-61

(C) Universidad Espíritu Santo - UEES

ISSN: 1390-6399 ISSN-e: 2602-8336 
which may have been the result of multiple independent origins and suggests that $A$. cantonensis migrated through intermediate and definitive hosts from endemic areas through human transport (Tokiwa et al., 2012).

In Brazil, phylogenetic analyzes were carried out by Monte et al. in 2012 on partial sequences of COI of $A$. cantonensis from 15 geographic isolates from Brazil. They determined the presence of three different COI haplotypes (AC5, AC8, and AC9). Most of the sample sequences were AC5 or AC8. In addition, a new haplotype ocurrence of the parasite called AC9 was described (Monte et al., 2012).

The data observed in this study showed that the A. cantonensis isolate from Caju (Rio de Janeiro state), which corresponds to AC9, is restricted to the port area and could have entered the country through trade from Asia. Similarly, Brazilian isolates from Pirituba (Sao Paulo state), Queimados and Niterói (Rio de Janeiro state), which correspond to the AC5 haplotype from Japan, are believed to have entered through Rio de Janeiro or São Paulo also from the Asian continent. This hypothesis is also considered for the most abundant Brazilian haplotype (AC8), which shows the possible spread from the arrival area to the southeast, northeast and north regions, probably through the giant African snail (Monte et al., 2012).

In a more recent study, $A$. cantonensis sequences from Thailand and Cambodia were classified into 13 different haplotypes. Two of these $A$. cantonensis haplotypes (AC2 and $\mathrm{AC} 5)$ had previously been reported from Brazil and Asia. A sample from Myanmar exhibited the AC2 haplotype. Additionally, four new AC10-AC13 haplotypes were found, which had not been previously observed in Thailand and Cambodia (Rodpai et al., 2016).

Recent studies carried out in Asia have shown that $A$. cantonensis has a great genetic diversity among the different regions analyzed (Tokiwa et al., 2012),(Rodpai et al., 2016),(Eamsobhana et al., 2017). This diversity of haplotypes shows that this parasite has been circulating in these regions for a long time. On the contrary, there is little or no genetic information on the parasite in other regions of the planet, such as the Americas region. With the sole exception of Brazil (Monte et al., 2012).

There is no genetic information on isolates of $A$. cantonensis in the rest of the countries of Latin America. For this reason, the present work is the first contribution to the knowledge of parasite genetics outside of Brazil in Latin America.

The result of the phylogenetic analysis showed that the Ecuadorian isolates are grouped into a single clade different from the other previously characterized groups (Monte et al., 2012),(Tokiwa et al., 2012),(Rodpai et al., 2016),(Eamsobhana et al., 2017), which represents a novelty for the genetic diversity of the parasite in Latin America and the rest of the world (Figure 1). 
Furthermore, it can also be observed that the sequence group from Ecuador shares a recent common ancestor with the AC5 and AC8 haplotypes from Brazil (Figure 1).

The 11 sequences obtained represent 11 provinces of Ecuador, located in different geographical and climatic regions. Even though the isolates are distributed in different areas, there are practically no genetic differences between them in the studied region of the cytochrome oxidase I gene. It is important to mention that the amplicon was sequenced by Sanger method which may favor abundant sequences from the amplicon. Even though, this result gives us indications that this parasite has been recently introduced in the country, which has prevented the existence of genetic divergence between the different circulating isolates. Other potential explanation for the low genetic difference may be due to high gene flow, which has been thought to constrain speciation by combining the gene pools of the groups, thus preventing the development of differences in genetic variation that would have led to full (Bolnick \& Nosil, 2007) This thesis is supported by the spillover of the parasite by land snail, A. fulica that has been associated with the wide distribution of $A$. cantonensis in China (Lv et al., 2009) or by the dispersion of the parasite to new areas mediated by rats (Simões et al., 2014).

Another finding is that the sequences from Ecuador present a recent common ancestor with two Brazilian haplotypes, that is, groups AC5 and AC8 (Monte et al., 2012). This result would indicate that there is a historical connection between the strains from both countries, Brazil reported the parasite for the first time in 2007(Caldeira et al., 2007), which will require new studies to confirm this relationship as well as the use of other technologies such as next-generation sequencing (NGS) to understand better the significance of these findings from the epidemiological point of view.(Frey \& Bishop-Lilly, 2015)

The existence of intermediate and definitive hosts of A. cantonensis in almost the entire country has contributed to the endemic nature of its distribution making the control of this disease a complex problem (Solorzano Alava et al., 2014). The main intermediate (A. fulica) and definitive ( $R$. rattus and $R$. norvegicus) hosts are not native species of Ecuador and have been considered among the 100 most important invasive species in the world.(Simberloff \& Rejmanek, 2019). The addition of new species invasives to an ecosystem can affect the well-being of people, whether through economics or health. Vectors of diseases and pathogens are spreading across continents due to human transport, land use change and climate change. Many species already present influence human well-being positively or negatively, and we must be concerned that the introduction of new species may result in novel biotic interactions and modify existing ones in the current ecosystems (Crowl et al., 2008).

\section{Acknowledgments}

The authors thank the members of the 
Parasitology Laboratory, Centro de Referencia Nacional de Parasitología y Micología, Instituto de Investigación en Salud Pública, INSPI, and the members of Microbiology laboratory, Facultad de Medicina, Universidad de Guayaquil.

\section{Conflict of Interest}

The author declares that he has no conflict of interest and that the content of the manuscript has not been previously published.

\section{Authors' contribution}

(LS, CB, HH, MR, LR) conceived the study and were in charge of overall direction and planning. (LS, AM, CB, FS), designed the study (LS, CB, FS), collected data ( LS, FS, CB, JP, AM, $\mathrm{MM}$ ) analysed and contributed to the interpretation of the results. All authors discussed the results and contributed to the final manuscript.

\section{References}

Apichat, V., Narongrit, S., Jittranuch, T., Anucha, W., Wilaiwan, P., Chamaiporn, F., Thatcha, Y., Bandid, M., Aunchalee, T., \& Paron, D. (2016). PHYLOGENY OF A N G I O S T R O N G Y L U S CANTONENSIS IN THAILAND BASED ON CYTOCHROME C OXIDASE SUBUNIT I GENE SEQUENCE. The Southeast Asian Journal of Tropical Medicine and Public Health, 47(3), 377-386.

Arenas, M. (2015). Trends in substitution models of molecular evolution. Frontiers in Genetics, 6, 319. https://doi.org/10.3389 /fgene.2015.00319
Bolnick, D. I., \& Nosil, P. (2007). NATURAL SELECTION IN POPULATIONS SUBJECT TO A MIGRATION LOAD. Evolution, 61(9), 2229-2243. https://doi. org/10.1111/j.1558-5646.2007.00179.x

Caldeira, R. L., Mendonça, C. L., Goveia, C. O., Lenzi, H. L., Graeff-Teixeira, C., Lima, W. S., Mota, E. M., Pecora, I. L., Medeiros, A. M. Z. de, \& Carvalho, O. dos S. (2007). First record of molluses naturally infected with Angiostrongylus cantonensis (Chen, 1935) (Nematoda: Metastrongylidae) in Brazil. Memórias Do Instituto Oswaldo Cruz, 102(7), 887-889. https://doi.org/10.1590/S007402762007000700018

Cedeño, M. G., Vargas, F. M., Rosero, A. R., Nuques, M. de L., Bolaños, E. S., Briones, M. T., Martínez, W. Z., \& Gómez, A. O. (2008). Meningitis eosinofílica por angiostrongylus cantonensis. Reporte de caso de autopsia. Medicina, 13(4), 312-318.

Chen, T. H. (1935). UN NOUVEAU NEMATODE PULMONAIRE, PULMONEMA CANTONENSIS, N. G., N. SP. DES RATS DE CANTON. Annales de Parasitologie, 8(4), 312-317.

Crowl, T. A., Crist, T. O., Parmenter, R. R., Belovsky, G., \& Lugo, A. E. (2008). The spread of invasive species and infectious disease as drivers of ecosystem change. Frontiers in Ecology and the Environment, 6(5), 238-246. https://doi.org/10.1890/070151

Eamsobhana, P., Song, S.-L., Yong, H.-S., Prasartvit, A., Boonyong, S., \& Tungtrongchitr, A. (2017). Cytochrome c oxidase subunit I haplotype diversity of Angiostrongylus cantonensis (Nematoda: Angiostrongylidae). Acta Tropica, 171, 141-145. https://doi.org/10.1016/j.actatro pica.2017.03.020

Frey, K. G., \& Bishop-Lilly, K. A. (2015). NextGeneration Sequencing for Pathogen 
Detection and Identification. En Methods in Microbiology (Vol. 42, pp. 525-554). Elsevier. https://doi.org/10.1016/bs.mim. 2015.06.004

Galtier, N., Nabholz, B., Glémin, S., \& Hurst, G. D. D. (2009). Mitochondrial DNA as a marker of molecular diversity: A reappraisal. Molecular Ecology, 18(22), 4541-4550. https://doi.org/10.1111/j.136 5-294X.2009.04380.x

Kearse, M., Moir, R., Wilson, A., Stones-Havas, S., Cheung, M., Sturrock, S., Buxton, S., Cooper, A., Markowitz, S., Duran, C., Thierer, T., Ashton, B., Meintjes, P., \& Drummond, A. (2012). Geneious Basic: An integrated and extendable desktop software platform for the organization and analysis of sequence data. Bioinformatics, 28(12), 1647-1649. https://doi.org/10.1093/bioinformatics/bt s199

Kumar, S., Stecher, G., Li, M., Knyaz, C., \& Tamura, K. (2018). MEGA X: Molecular Evolutionary Genetics Analysis across Computing Platforms. Molecular Biology and Evolution, 35(6), 1547-1549. https://doi.org/10.1093/molbev/msy096

Legislation for the protection of animals used for scientific purposes - Environment European Commission. (s. f.). Recuperado 29 de octubre de 2020, de https://ec.europa.eu/environment/chemic als/lab_animals/legislation_en.htm

Lindo, J. F., Escoffery, C. T., Reid, B., Codrington, G., Cunningham-Myrie, C., \& Eberhard, M. L. (2004). Fatal autochthonous eosinophilic meningitis in a Jamaican child caused by Angiostrongylus cantonensis. The American Journal of Tropical Medicine and Hygiene, 70(4), 425-428.

Lv, S., Zhang, Y., Liu, H.-X., Hu, L., Yang, K., Steinmann, P., Chen, Z., Wang, L.-Y., Utzinger, J., \& Zhou, X.-N. (2009).
Invasive Snails and an Emerging Infectious Disease: Results from the First National Survey on Angiostrongylus cantonensis in China. PLOS Neglected Tropical Diseases, 3(2), e368. https://doi.org/10.1371/journal.pntd.0000 368

Martini-Robles L, Gomez E, Muzzio J, Solorzano L. (2016). Descripcion del primer foco de transmision natural de Angiostrongylus cantonensis en Ecuador. En A. Martini Robles, Dorta - Contreras, Angiostrongylus cantonensis. Emergencia en América (pp. 209-220).

Monte, T. C., Simões, R. O., Oliveira, A. P. M., Novaes, C. F., Thiengo, S. C., Silva, A. J., Estrela, P. C., \& Júnior, A. M. (2012). Phylogenetic relationship of the Brazilian isolates of the rat lungworm Angiostrongylus cantonensis (Nematoda: Metastrongylidae) employing mitochondrial COI gene sequence data. Parasites \& Vectors, 5, 248. https://doi.org/10.1186/1756-3305-5-248

Moreira, V. L. C., Giese, E. G., Melo, F. T. V., Simões, R. O., Thiengo, S. C., Maldonado, A., \& Santos, J. N. (2013). Endemic angiostrongyliasis in the Brazilian Amazon: Natural parasitism of Angiostrongylus cantonensis in Rattus rattus and $\mathrm{R}$. norvegicus, and sympatric giant African land snails, Achatina fulica. Acta Tropica, 125(1), 90-97. https://doi.org/10.1016/j.actatropica.2012 .10 .001

Muzzio, J. (2014, agosto 15). Hospederos intermediarios de Angiostrongylus cantonensis en Ecuador. https://www.eae-publishing. com/catalog/details//store/gb/book/978-3 -659-01021-7/hospederos-intermediarios -de-angiostrongylus-cantonensis-en-ecua dor

Paraense, W. L., \& Paraense, W. L. (1995). Lymnaea cousini Jousseaume, 1887, from Ecuador (Gastropoda: Lymnaeidae). Memórias Do 
Instituto Oswaldo Cruz, 90(5), 605-609. https://doi.org/10.1590/S0074-02761995 000500011

Pincay, T., García, L., Narváez, E., Decker, O., Martini, L., \& Moreira, J. (2009). Angiostrongiliasis por Parastrongylus (Angiostrongylus) cantonensis en Ecuador. Primer informe en Sudamérica. Tropical Medical Int Health, 14(2), S37.

Rodpai, R., Intapan, P. M., Thanchomnang, T., Sanpool, O., Sadaow, L., Laymanivong, S., Aung, W. P., Phosuk, I., Laummaunwai, P., \& Maleewong, W. (2016). Angiostrongylus cantonensis and A. malaysiensis Broadly Overlap in Thailand, Lao PDR, Cambodia and Myanmar: A Molecular Survey of Larvae in Land Snails. PloS One, 11(8), e0161128. https://doi.org/10.1371/jour nal.pone. 0161128

Simberloff, D., \& Rejmanek, M. (Eds.). (2019). 100 of the World's Worst Invasive Alien Species: A Selection From The Global Invasive Species Database. En Encyclopedia of Biological Invasions (pp. 715-716). University of California Press. https://california.degruyter.com/ view/book/9780520948433/10.1525/978 0520948433-159.xml

Simões, R. O., Júnior, A. M., Olifiers, N., Garcia, J. S., Bertolino, A. V. F., \& Luque, J. L. (2014). A longitudinal study of Angiostrongylus cantonensis in an urban population of Rattus norvegicus in Brazil: The influences of seasonality and host features on the pattern of infection. Parasites \& Vectors, 7(1), 100. https://doi.org/10.1186/1756-3305-7-100

Solorzano Alava, L. F., Martini Robles, L., Hernandez, H., Sarracent, J., Muzzio, J., \& Rojas, L. (2014). Angiostrongylus cantonensis: Un parásito emergente en Ecuador. Revista Cubana Medicina Tropical, 66(1).
Thiengo, S. C., de Oliveira Simões, R., Fernandez, M. A., \& Júnior, A. M. (2013). Angiostrongylus cantonensis and Rat Lungworm Disease in Brazil. Hawai'i Journal of Medicine \& Public Health, 72(6 Suppl 2), 18-22.

Tokiwa, T., Harunari, T., Tanikawa, T., Komatsu, N., Koizumi, N., Tung, K.-C., Suzuki, J., Kadosaka, T., Takada, N., Kumagai, T., Akao, N., \& Ohta, N. (2012). Phylogenetic relationships of rat lungworm, Angiostrongylus cantonensis, isolated from different geographical regions revealed widespread multiple lineages. Parasitology International, 61(3), 431-436. https://doi.org/10.1016 /j.parint.2012.02.005

Wallace, G. D., \& Rosen, L. (1967). Studies on eosinophilic meningitis. IV. Experimental infection of fresh-water and marine fish with Angiostrongylus cantonensis. American Journal of Epidemiology, 85(3), 395-402. https://doi.org/10.1093/oxfordjournals.aj e.a120701

Wang, Q.-P., Lai, D.-H., Zhu, X.-Q., Chen, X.-G., \& Lun, Z.-R. (2008). Human angiostrongyliasis. The Lancet. Infectious Diseases, 8(10), 621-630. https://doi.org/10.1016/S1473-3099(08)7 0229-9 